\title{
ANALISIS INSTRUMEN TES AKHIR KEMAMPUAN KOMUNIKASI MATEMATIKA UNTUK SISWA SMP PADA MATERI FUNGSI DAN RELASI
}

\author{
Rena Revita ${ }^{1}$, Annisah Kurniati ${ }^{2}$, Lies Andriani ${ }^{3}$ \\ ${ }^{1,2,3}$ Fakultas Tarbiyah dan Keguruan, UIN Sultan Syarif Kasim Riau \\ Email : Rena.revita@uin-suska.ac.id
}

\begin{abstract}
This study aims to determine the quality of the final test instrument of student's mathematical communication skills of SMP on the subject of functions and relations. The method used in this research is quantitative descriptive method. While the data in this study was collected by field data collection method. The results obtained from this study is the information about the validity, reliability, different power, and the level of difficulty of instrument. Based on the results of the analysis conducted, for the validity of the instrument obtained conclusion that of the 6 questions that will be tested are valid, by obtaining the value of $t$ arithmetic greater than the value of $\mathrm{t}$ table that is equal to 1.330 . As for reliability, the results obtained that the test will be reliabel by obtaining the reliability value of $\mathrm{r} 11=0,707563$. When compared with the value of $\mathrm{r}$ table product moment at a significant level of $5 \%$ of 0.444 , it can be concluded that the problem will be tested reliabel used as a data collection instrument. Based on the results of difficulty level analysis, there are 4 problems with moderate difficulty and two problems with easy difficulty. As for the different power, based on the results of different power analysis, there are 5 quistions with good different power good and one quistions with good enough different power.
\end{abstract}

\section{Keyword : Instrument, validity, reliability, level of difficulty, different power}

\begin{abstract}
Abstrak
Penelitian ini bertujuan untuk mengetahui kualitas instrumen tes akhir kemampuan komunikasi matematika siswa SMP pada materi fungsi dan relasi. Metode yang digunakan dalam penelitian ini adalah metode deskriptif kuantitatif. Sedangkan data dalam penelitian ini dikumpulkan dengan metode pengumpulan data lapangan. Hasil yang diperoleh dari penelitian ini adalah informasi berupa validitas soal, reliabilitas soal, daya beda, dan tingkat kesukaran pada soal. Berdasarkan hasil analisis yang dilakukan, untuk validitas soal diperoleh kesimpulan bahwa dari 6 soal uraian yang akan diujikan dinyatakan valid, dengan memperoleh nilai t hitung lebih besar dari nilai t tabel yaitu sebesar 1,330. Sedangkan untuk reliabilitas, diperoleh hasil bahwa soal yang akan diujikan tersebut reliabel dengan memperoleh nilai reliabilitas sebesar $r_{11}=0,707563$. Jika dibandingkan dengan nilai $r$ tabel product moment pada taraf signifikan 5\% yaitu 0,444, maka dapat disimpulkan bahwa soal yang akan diujikan reliabel untuk dijadikan alat pengumpul data. Berdasarkan hasil analisis tingkat kesukaran, terdapat 4 buah soal dengan tingkat kesukaran sedang dan dua soal dengan tingkat kesukaran mudah. Sedangkan untuk daya beda, berdasarkan hasil analisis daya beda, terdapat 5 soal dengan daya beda baik dan satu soal dengan daya beda cukup baik.
\end{abstract}

Kata kunci : Instrumen, validitas, reliabilitas, tingkat kesukaran, daya beda

Pembelajaran dalam matematika memiliki beberapa tujuan, diantaranya sebagaimana yang disebutkan dalam peraturan menteri pendidikan nomor 22 tahun 2006 mengenai tujuan pembelajaran matematika salah satunya adalah agar peserta didik memiliki kemampuan mengkomunikasikan gagasan dengan simbol, tabel, diagram, atau media lain untuk memperjelas keadaan atau masalah. Untuk itu, penting bagi siswa untuk dapat menguasai kemampuan berkomunikasi secara matematika dalam pembelajaran agar setiap siswa dapat dengan mudah bertanya atau menyampaikan ide-ide atau gagasan yang dimilikinya dalam proses pembelajaran. Baroody (dalam Firdaus, 2005:4) menyatakan bahwa : 
"Ada dua alasan penting mengapa komunikasi dalam matematik perlu dikembangkan dikalangan siswa. Alasan yang pertama adalah bahwa mathematice as language, artinya matematika tidak hanya sekedar alat bantu berpikir, alat untuk menemukan pola, menyelesaikan masalah ataupun mengambil kesimpulan tetapi juga sebagai alat berharga untuk mengkomunikasikan berbagai ide secara jelas, tepat dan cermat. Kedua mathematics leatning as social activity: artinya sebagai aktivitas sosial dalam pembelajaran matematika, juga sebagai wahana interaksi antar siswa dan juga komunikasi antara guru dan siswa".

Untuk mencapai tujuan pembelajaran matematika tersebut guru hendaknya menekankan proses pembelajaran pada prinsip-prinsip pembelajaran matematika. Prinsip-prinsip dalam proses pembelajaran tersebut menyebabkan peserta didik dapat mengembangkan ilmu pengetahuan, daya kreatif dan bertanggung jawab terhadap jalannya proses pembelajaran matematika. Prinsip-prinsip pembelajaran matematika menurut Risnawati (2008: 13) yaitu: a) Melibatkan siswa secara langsung dalam proses pembelajaran matematika; b) Penilaian kemampuan siswa terhadap materi yang telah dipelajari; c) Siswa melakukan penilaian terhadap diri sendiri; d) Menyediakan kesempatan untuk berlatih dan mengulang; e) Generalisasi kesituasi baru; f) Membangun fondasi yang kokoh tentang konsep dan keterampilan matematika; g) Menyajikan program matematika yang seimbang; h) Suasana belajar yang efektif; i) Pemberian penghargaan terhadap hasil belajar peserta didik.

Berdasarkan uraian tersebut, salah satu prinsip yang harus dijalankan dalam proses pembelajaran adalah penilaian kemampuan siswa terhadap materi yang telah dipelajari. Dalam proses penilaian tersebut guru lah yang berperan dalam penyusunan evaluasi, dan setiap guru dituntut untuk bertanggung jawab dalam merencanakan dan melaksanakan evaluasi tersebut dengan baik. Menurut Ali Hamzah (2014) "evaluasi adalah sarana untuk mendapatkan informasi yang diperoleh dari proses pengumpulan dan pengolahan data". Di dalam evaluasi terdapat pengukuran dan penilaian. Evaluasi akan berjalan baik apabila memenuhi prinsip-prinsip evaluasi sebagaimana yang dikatakan oleh Ali Hamzah (2014), prinsip-prinsip evaluasi meliputi keterpaduan, keterlibatan peserta didik, koherensi, pedagogis, dan akuntabilitas.

Stufflebeam dan Shinkfield (1985) mendefinisikan "the process of delineating, obtaining, and providing descriptive and judgmental information about the wort and merit of same object's goals, design, implementation and impact in order to guide decision making, serve needs for accountability, and promote understanding of the involve phenomend". Artinya evaluasi adalah suatu proses menggambarkan, mengumpulkan, dan menyajikan deskriptif dan informasi yang menentukan nilai dan manfaat beberapa tujuan, objek, desain, implementasi, dan dampak yang berguna untuk pembuat keputusan, penyajian keperluan-keperluan untuk pertanggung jawaban dan mempromosikan pemahaman terhadap fenomena yang terlibat. Sedangkan Fitzpatrick, J.L., Sander, J.R., \& Worthen, B.L. (2011) menyatakan bahwa "evaluasi adalah sebuah proses mengidentifikasi, mengklarifikasi, 
dan menerapkan kriteria yang tepat, untuk menentukan nilai objek evaluasi”.

Berdasarkan uraian tersebut, proses evaluasi tersebut merupakan kegiatan untuk membuat keputusan dengan memperhatikan kaidah-kaidah yang telah ditetapkan dalam evalausi. Sebagaimana yang dikatakan Hood, S. \& Hopson, R.K (2008: 416), "Evaluation is a process that requires the meaningful and complete participation of all parties in the education process", Proses pelaksanaan evaluasi membutuhkan dukungan dan kerjasama dari semua pihak dari guru, siswa dan sekolah. Dalam proses evaluasi tersebut juga dibutuhkan instrumen evaluasi yang merupakan alat ukur yang digunakan untuk mengumpulkan dan mengolah informasi dalam rangka menentukan pencapaian hasil belajar peserta didik. Menurut standar Penilaian Pendidikan dalam Permendiknas Nomor 20 Tahun 2007, kegiatan guru dalam penilaian hasil belajar yang terkait dengan instrumen dan teknik penilaian hasil belajar adalah sebagai berikut: a) mengembangkan indikator pencapaian kompetensi dasar dan memilih teknik penilaian yang sesuai pada saat menyusun silabus mata pelajaran; b) mengembangkan instrumen dan pedoman penilaian sesuai dengan bentuk dan teknik penilaian yang dipilih; c) melaksanakan tes, pengamatan, penugasan, dan/atau bentuk lain yang diperlukan. Berdasarkan peraturan tersebut, maka guru bertanggung jawab melakukan penilaian dengan mempersiapkan instrumen penilaian yang baik.

Salah satu instrumen evaluasi yang biasa digunakan dalam proses pembelajaran adalah tes. Tes menurut Hartono (2010) merupakan serangkaian pertanyaan atau latihan yang digunakan untuk mengukur pengetahuan, kemampuan atau bakat atau intelegensia, keterampilan yang dimiliki oleh individu atau kelompok. Intrumen yang akan digunakan dalam hal ini adalah tes haruslah memiliki kualitas yang baik. Untuk itu, sebelum digunakan terlebih dahulu dilakukan analisis item instrumen terhadap intrumen evaluasi yang akan digunakan. Sebagaimana yang disebutkan oleh Ali Hamzah (2014) dalam menganalisis kualitas instrumen evaluasi dilakukan uji validitas, uji reliabilitas, daya beda instrumen dan tingkat kesukaran terhadap instrumen tersebut.

Proses evaluasi dalam penilaian hasil belajar merupakan hal penting yang harus dilakukan seorag guru dalam proses pembelajaran. Namun banyak guru yang belum mampu memilih alat evaluasi yang baik. Pada umumnya dalam penyusunan alat evaluasi ini, guru belum bisa mengidentifikasi soal yang baik, kurang baik dan soal yang jelek.

Zamsir dan hasnawati (2014) dalam penelitianya menunjukkan bahwa mayoritas guru berpendapat penyebab kesulitan belajar siswa pada waktu mengikuti ujian terutama pada tiga aspek, yaitu 1) materi belum tuntas diajarkan, 2) materi sulit dipahami oleh siswa, 3) siswa belum terbiasa menjawab model soal yang diujikan. Sedangkan menurut Tika Dwi Rahayu, Bambang Hari Purnomo dan Sudikin (2014) tingkat kesukaran soal pilihan ganda buatan guru belum proporsional dan tidak sesuai antara ranah kognitif yang ditetapkan oleh guru dengan ranah kognitif Taksonomi Bloom.

Berdasarkan beberapa hasil penelitian tersebut, maka dalam pembuatan soal tes untuk evaluasi guru haruslah benar-benar memperhatikan kualitas soal yang akan dikerjakan oleh peserta didik dengan melakukan analisis butir soal sehingga soal yang digunakan sebagai alat evaluasi dapat 
mengukur hasil belajar yang sesuai dengan apa yang diinginkan.

Berdasarkan latar belakang yang telah dijelaskan tersebut, maka masalah dalam penelitian ini adalah bagaimana kualitas instrumen tes akhir komunikasi matematika untuk anak SMP pada materi fungsi dan relasi.

\section{METODE}

Jenis penelitian yang digunakan adalah penelitian lapangan (field research) dengan pendekatan deskriptif. Subjek dalam penelitian ini adalah siswa SMP yang berjumlah sebanyak 20 orang siswa. Objek penelitian ini adalah kualitas instrumen tes kemampuan komunikasi matematika pada tes uji coba materi fungsi dan relasi yang dilihat dari segi validitas, reliabilitas, tingkat kesukaran dan daya pembeda soal. Data yang diperoleh dari penelitian ini yaitu data hasil tes matematika berupa lembar jawaban soal. Analisis item instrumen yang akan dilakukan dijelaskan sebagai berikut.

\section{Uji Validitas Butir Soal}

Instrumen pengukuran dapat dikatakan mempunyai validitas yang tinggi apabila instrumen tersebut menjalankan fungsi ukurannya memberikan hasil ukuran sesuai dengan maksud dilakukan pengukuran tersebut. Validitas merupakan validitas yang diestimasi lewat pengujian terhadap kelayakan atau relevansi isi tes melalui analisis rasional oleh panel yang berkompeten atau melalui expert judmenet (Saifuddin Azwar, 2013: 42). Sedangkan Menurut Ali Hamzah (2014:214) valid berarti sahih, yang berarti keabsahan intrumen itu tidak diragukan lagi. Suatu instrumen pengukuran dikatakan memiliki validitas yang tinggi menurut Ali Hamzah (2014:215) adalah apabila instrumen tersebut menjalankan fungsi ukurnya atau memberikan hasil ukur yang sesuai dengan maksud dilakukannya pengukuran tersebut.

Menurut Hartono (2010:85) validitas instruman penelitian baik dalam bentuk tes, angket maupun observasi dapat diketahui dengan melakukan analisis faktor, yaitu dengan mengkorelasikan antara skor item instrumen dengan skor totalnya. Hal ini dapat dilakukan dengan korelasi Product Moment. Rumus yang dapat digunakan dengan menggunakan nilai asli sebagaimana yang dijelaskan oleh Ali Hamzah (2014:220) adalah sebagai berikut:

$$
\mathrm{r}_{\mathrm{xy}}=\frac{\mathrm{N} \sum \mathrm{XY}-\left(\sum \mathrm{X}\right)\left(\sum \mathrm{Y}\right)}{\sqrt{\left[\mathrm{N}\left(\sum \mathrm{X}^{2}\right)-\left(\sum \mathrm{X}\right)^{2}\right]\left[\mathrm{N}\left(\sum \mathrm{Y}^{2}\right)-\left(\sum \mathrm{Y}\right)^{2}\right]}}
$$

Keterangan :

$\mathrm{r}_{\mathrm{xy}} \quad=$ koefisien korelasi antara variabel $\mathrm{X}$ dan Variabel $\mathrm{Y}$, dua variabel yang di korelasikan

$\sum X \quad=$ Jumlah Rerata Nilai $\mathrm{X}$

$\sum Y \quad=$ Jumlah Rerata Nilai $Y$

$\mathrm{N}=$ Jumlah peserta didik 
Setelah diperoleh nilai koefisien variabel $\left(\mathrm{r}_{\mathrm{xy}}\right)$ untuk setiap item soal, dilanjutkan dengan menghitung nilai $t_{\text {hitung }}$ dan membandingkan dengan $t_{\text {tabel }}$ pada $\mathrm{df}=18$ dan alfa $0,05(5 \%)$. Hartono (2010:90) mengatakan untuk menentukan apakah butir soal tersebut valid atau tidak, dapat ditentukan dengan ketentuan yaitu:

- jika $t_{\text {hitung }}$ lebih kecil dari $(<) t_{\text {tabel }}$ maka butir tersebut invalid (tidak valid),

- Jika thitung lebih besar dari (>) tabel maka butir soal tersebut valid.

\section{Uji Reliabilitas Butir Soal}

Tahap kedua adalah melakukan uji reliabilitas instrumen. Pengukuran reliabilitas instrument butir soal menggunakan koefisien Alpha Cronbach, reliabilitas instrumen dalam penelitian ini diperoleh melalui teori yang relevan, sehingga kriteria penetapan penafsiran batas menimal koefisien reliabilitas yang digunakan dalam penelitian ini mengacu pendapat Djemari Mardapi (2012: 164) yaitu minimal 0,70. Artinya suatu instrumen dikatakan reliabel jika mempunyai nilai koefisien sekurang-kurangnya 0,70 .

Penelitian ini dilakukan dengan cara memberikan instrumen kepada responden. Menurut Suharsimi Arikunto (1996:168), reliabilitas menunjuk pada instrumen yang dianggap dapat dipercaya untuk digunakan sebagai alat pengumpul data karena instrumen tersebut sudah baik. Tingkat keandalan (reliabilitas) instrumen diperoleh dengan cara menganalisis butir-butir instrumen yang terbukti valid. Secara umum, semakin tinggi koefisien reliabilitas menunjukkan bahwa tingkat kehandalan instrumen semakin baik. Menurut Ali Hamzah (2014:230), "suatu hasil pengukuran hanya dapat dipercaya apabila dalam beberapa kali pelaksanaan pengukuran terhadap kelompok yang sama diperoleh hasil pengukuran yang relatif sama". Untuk melakukan analisis reliabilitas instrumen dalam penelitian ini digunakan rumus alpha untuk menemukan niLai $r_{\text {hitung }}\left(r_{11}\right)$ sebagaimana yang disebutkan oleh Hartono (2011:81) dapat digunakan rumus sebagai berikut:

$$
\mathrm{r}_{11}=\left(\frac{k}{k-1}\right)\left(1-\frac{\sum S i}{S t}\right)
$$

keterangan:

$\mathrm{r}_{11} \quad=$ nilai reliabilitas

$\sum S i \quad=$ jumlah varians skor tiap-tiap item

St $\quad=$ varians total

$\mathrm{K} \quad=$ jumlah item 


\section{Tabel 1}

Proporsi Reliabilitas Tes

\begin{tabular}{|c|c|}
\hline Reliabilitas Tes & Evaluasi \\
\hline $0,80<\mathrm{r}_{11} \leq 1,00$ & Sangat tinggi \\
\hline $0,60<\mathrm{r}_{11} \leq 0,80$ & Tinggi \\
\hline $0,40<\mathrm{r}_{11} \leq 0,60$ & Sedang \\
\hline $0,20<\mathrm{r}_{11} \leq 0,40$ & Rendah \\
\hline $0,00<\mathrm{r}_{11} \leq 0,20$ & Sangat rendah \\
\hline
\end{tabular}

\section{Uji Daya Beda Butir Soal}

Daya pembeda soal adalah pengukuran sejauh mana suatu soal mampu membedakan siswa yang berkemampuan tinggi dengan siswa yang berkemampuan rendah. Semakin tinggi koefisien daya pembeda suatu soal, semakin mampu soal tersebut membedakan antara siswa yang menguasai kompetensi dengan siswa yang kurang menguasai kompetensi (Arifin, 2014:273). Analisis daya beda soal perlu dilakukan untuk mengetahu perbedaan kemampuan individu peserta didik berdasarkan butir soal tersebut, dengan tujuan untuk mengetahui kesanggupan siswa yang tergolong mampu dengan siswa yang tergolong kurang atau lemah prestasinya. Artinya, bila soal tersebut diberikan kepada anak yang mampu, hasilnya menunujukkan prestasi yang tinggi dan bila diberikan kepada siswa yang lemah, hasilnya rendah.

Selanjutnya untuk mengetahui daya beda item soal dalam Suharsimi Arikunto (1996:218-219) digunakan rumus sebagai berikut:

$$
\mathrm{D}=\frac{B_{A}}{J_{A}}-\frac{B_{B}}{J_{B}}=\mathrm{P}_{\mathrm{A}}-\mathrm{P}_{\mathrm{B}}
$$

Keterangan:

$\mathrm{J}=$ Jumlah peserta tes

$\mathrm{J}_{\mathrm{A}} \quad=$ Banyaknya peserta kelompok atas

$\mathrm{J}_{\mathrm{B}} \quad=$ Banyaknya peserta kelompok bawah

$\mathrm{B}_{\mathrm{A}} \quad=$ Banyaknya peserta kelompok atas yang menjawab soal dengan benar

$\mathrm{B}_{\mathrm{B}} \quad=$ Banyaknya peserta kelompok bawah yang menjawab soal dengan benar

Berikut ini adalah tabel Klasifikasi Interpretasi Daya Pembeda soal menurut Ali Hamzah (2014). 
Tabel 2

Klasifikasi Interpretasi Daya Pembeda

\begin{tabular}{|c|c|}
\hline Nilai DP & Interpretasi \\
\hline $\mathrm{DP} \leq 0,00$ & Sangat Jelek \\
\hline $0,00<\mathrm{DP} \leq 0,20$ & Jelek \\
\hline $0,20<\mathrm{DP} \leq 0,40$ & Cukup \\
\hline $0,40<\mathrm{DP} \leq 0,70$ & Baik \\
\hline $0,70<\mathrm{DP} \leq 1,00$ & Baik Sekali \\
\hline
\end{tabular}

\section{Uji Tingkat Kesukaran Butir Soal}

Uji yang dilakukan selanjutnya adalah Uji tingkat kesukaran butir soal. Tingkat kesukaran adalah salah satu indikator yang dapat menunjukkan kualitas suatu butir soal apakah termasuk dalam kategori mudah, sedang, atau sukar. Soal dikatakan baik apabila soal yang diberikan tidak terlalu mudah atau tidak terlalu sukar, sebalinya pula kalau soal yang diberikan terlalu sukar akan menyebabkan siswa putus asa dan tidak semangat untuk mengerjakan soal-soal.

Menurut Ali Hamzah (2014) tingkat kesukaran butir soal dapat dihitung dengan menggunakan rumus berikut :

$$
\mathrm{D}=\frac{B a+B b}{J a+J b}=\frac{\mathrm{B}}{\mathrm{JS}}
$$

Keterangan:

D = Indeks kesukaran soal

$\mathrm{Ba}=$ Jumlah yang menjawab benar soal tersebut dari kelompok atas

$\mathrm{Bb}=$ Jumlah yang menjawab benar soal tersebut dari kelompok bawah

$\mathrm{Ja}=$ Jumlah lembar jawaban kelompok atas

$\mathrm{Jb}=$ jumlah lembar jawaban kelompok bawah

B = Banyak siswa yang menjawab soal dengan benar

JS = Jumlah seluruh siswa peserta tes

Berikut ini adalah tabel Klasifikasi Interpretasi Taraf Kesukaran menurut Ali Hamzah (2014).

Tabel 3

Klasifikasi Interpretasi Tingkat Kesukaran

\begin{tabular}{|c|c|}
\hline Nilai Tk & Interpretasi \\
\hline $\mathrm{P}=0,00$ & Sangat Sukar \\
\hline $0,00<\mathrm{P} \leq 0,30$ & Sukar \\
\hline $0,30<\mathrm{P} \leq 0,70$ & Sedang \\
\hline $0,70<\mathrm{P} \leq 1,00$ & Mudah \\
\hline $\mathrm{P}=1,00$ & Sangat Mudah \\
\hline
\end{tabular}




\section{HASIL DAN PEMBAHASAN}

Soal tes yang disiapkan untuk tes akhir adalah soal yang berkaitan dengan kemampuan komunikasi matematika. Komunikasi matematika merupakan suatu proses penyampaian atau pertukaran informasi secara lisan maupun tulisan yang terjadi dalam hubungan di lingkungan kelas, dimana pesan yang disampaikan maupun yang diterima adalah pesan yang berisi materi pelajaran matematika yang dipelajari siswa, baik itu berupa fakta, konsep, rumus, ataupun teknik dalam penyelesaian suatu masalah matematika. Dalam proses komunikasi tersebut pihak-pihak yang terlibat adalah guru dan peserta didik.

Tercapainya tujuan pembelajaran matematika dalam hal ini adalah kemampuan komunikasi matematika ditandai dengan terpenuhinya indikator-indikator yang menjadi tolak ukur seorang peserta didik mampu berkomunikasi dengan baik dalam proses pembelajaran matematika. Sebagaimana yang disebutkan oleh Karunia Eka Lestari dan Mohammad Ridwan Yudhanegara (2017:83), komunikasi matematis memiliki indikator yaitu : a) menghubungkan benda nyata, gambar, dan diagram ke dalam ide matematika; b) menjelaskan ide, situasi, dan relasi matematika secara lisan atau tulisan dengan benda nyata, gambar, grafik dan aljabar; c) menyatakan peristiwa sehari-hari dalam bahasa matematika; d) mendengarkan, diskusi dan menulis tentang matematika; e) membaca dengan pemaham suatu presentasi matematika tertulis; f) menyusun pertanyaan matematika yang relevan dengan situasi masalah; g) membuat konjektur, menyusun argumen, merumuskan definisi dan generalisasi.

Berdasarkan indikator tersebut dalam penelitian ini peneliti akan membahas kemampuan komunikasi matematika secara tertulis dan dikatakan baik apabila memenuhi indikator sebagai berikut: a) Kemampuan menggambar (drawing), meliputi kemampuan siswa dalam mengungkapkan ide-ide dalam bentuk grafik, gambar, maupun diagram; b) Kemampuan menulis (written Text), meliputi kemampuan memberikan penjelasan dan alasan secara matematika dengan bahasa matematika yang benar dan mudah dipahami; c) Kemampuan mengekspresikan matematika (mathematical expression), meliputi kemampuan membuat permodelan matematika. Indikator-indikator tersebut diukur dengan menggunakan rubrik penilaian sebagai berikut : 
Tabel 4

Kriteria Pemberian Skor Komunikasi Matematika

\begin{tabular}{|c|c|c|c|}
\hline Skor & $\begin{array}{c}\text { Menulis } \\
\text { (Written texts) }\end{array}$ & Menggambar (Drawing) & $\begin{array}{l}\text { Ekpresi Matematis } \\
\text { (Mathematical Expression) }\end{array}$ \\
\hline 0 & \multicolumn{3}{|c|}{$\begin{array}{l}\text { Tidak ada jawaban, kalaupun ada hanya memperlihatkan tidak memahami konsep sehingga } \\
\text { informasi yang diberikan tidak berarti apa-apa }\end{array}$} \\
\hline 1 & $\begin{array}{l}\text { Hanya sedikit dari penjelasan } \\
\text { yang benar }\end{array}$ & $\begin{array}{l}\text { Hanya sedikit dari gambar, } \\
\text { diagram, atau tabel yang } \\
\text { benar. }\end{array}$ & $\begin{array}{l}\text { Hanya sedikit dari model } \\
\text { matematika yang benar. }\end{array}$ \\
\hline 2 & $\begin{array}{l}\text { Penjelasan secara matematis } \\
\text { masuk akal namun hanya } \\
\text { sebagian lengkap dan benar }\end{array}$ & $\begin{array}{l}\text { Melukiskan, diagram, } \\
\text { gambar, atau tabel namun } \\
\text { kurang lengkap dan benar }\end{array}$ & $\begin{array}{l}\text { Membuat model matematika } \\
\text { dengan benar, namun salah } \\
\text { dalam mendapatkan solusi. }\end{array}$ \\
\hline 3 & $\begin{array}{l}\text { Penjelasan secara matematis } \\
\text { masuk akal dan benar, } \\
\text { meskipun tidak tersusun } \\
\text { secara logis atau terdapat } \\
\text { sedikit kesalahan bahasa. }\end{array}$ & $\begin{array}{l}\text { Melukiskan, diagram, } \\
\text { gambar, atau tabel secara } \\
\text { lengkap dan benar }\end{array}$ & $\begin{array}{l}\text { Membuat model matematika } \\
\text { dengan benar, kemudian } \\
\text { melakukan perhitungan atau } \\
\text { mendapatkan solusi secara } \\
\text { benar dan lengkap }\end{array}$ \\
\hline 4 & $\begin{array}{l}\text { Penjelasan secara matematis } \\
\text { masuk akal dan jelas serta } \\
\text { tersusun secara logis }\end{array}$ & & \\
\hline & Skor Maksimal $=4$ & Skor Maksimal $=3$ & Skor Maksimal = \\
\hline
\end{tabular}

Diadaptasi dari Cai, Lane, dan Jakabcsin (1996) dalam Tesis Halmaheri (2004)

\section{Soal Tes Kemampuan Komunikasi}

Berikut ini adalah soal tes akhir komunikasi matematika yang dibuat dalam 6 soal essay yang dibuat berdasarkan indikator menggambar, menulis dan mengekspresikan matematika.

1. Diketahui $\mathrm{A}=\{1,2,3,4,5\}$ dan fungsi $f: A \rightarrow A$ ditentukan oleh : $1 \rightarrow 2,2 \rightarrow 3,3 \rightarrow 4,4 \rightarrow$ $5,5 \rightarrow 1$. Lukislah diagram panah untuk fungsi $f$ !

2. Fungsi $f$ dinyatakan dengan $f(x)=3 x-2$ dan daerah asal $\{-3,-2,-1,0,1,2,3\}$.

Tentukan $f(-3)$ dan $f(4)$ !

3. Fungsi $g$ ditentukan dengan $h(x)=2 x+8$. Tentukan nilai $\mathrm{n}$, jika $h(n)=40$.

4. Diberikan sebuah fungsi $g: x \rightarrow 4-2 x$ dengan daerah asal $\{-4,-3,-2,-1,0,1,2,3,4\}$. Tulislah rumus dari fungsi $g$ dan buatlah tabel fungsi $g$ !

5. Gambarlah grafik fungsi kuadrat $f$ yang ditentukan oleh $f x)=25-x^{2}$ dengan daerah asal $\{x \mid-$ $5 \leq x \leq 5, x \in R\}$.

6. Suatu fungsi ditentukan dengan rumus $f(x)=a x+b$. jika diketahui $f(-3)=20 \operatorname{dan} f(2)=$ 10 , tentukanlah bentuk fungsinya.

\section{Uji Validitas Butir Soal}

Hasil analisis butur soal untuk uji validitas soal dapat dilihat pada Tabel 5 berikut ini. 


\section{Tabel 5}

\section{Hasil Uji Validitas Butir Soal}

\begin{tabular}{|l|l|c|c|}
\hline No & $\mathbf{T}_{\text {hitung }}$ & $\mathbf{T}_{\text {tabel }} \mathbf{d f}=\mathbf{1 8}$ & Keterangan \\
\hline 1. & 6,687 & 1,330 & Valid \\
\hline 2. & 5,309 & 1,330 & Valid \\
\hline 3. & 2,982 & 1,330 & Valid \\
\hline 4. & 1,918 & 1,330 & Valid \\
\hline 5. & 2,073 & 1,330 & Valid \\
\hline 6. & 3,315 & 1,330 & Valid \\
\hline
\end{tabular}

Berdasarkan hasil analisis data yang diperoleh dari hasil tes akhir peserta didik, diperoleh hasil bahwa keenam soal kemampuan komunikasi matematika peserta didik berada pada kategori valid dengan nilai $\mathrm{T}$ hitung lebih besar dari nilai $\mathrm{T}$ tabel.

\section{Uji Reliabilitas Butir Soal}

hasil uji reliabilitas butir soal dilakukan dengan menganalisis reliabilitas tes dengan rumus alpha untuk menemukan niai $r_{\text {hitung }}\left(r_{11}\right)$ dan membandingkannya dengan $r_{\text {tabel }}$ product moment dengan ketentuan sebagai bila $r_{\text {hitung }}$ lebih besar dari $r_{\text {tabel }}$ berarti reliabel, dan bila $r_{\text {hitung }}$ lebih kecil dari $r_{\text {tabel }}$ berarti tidak reliabel.

Setelah melakukan analisis uji reliabelitas dengan bantuan program microsoft excel diperoleh nilai $\mathrm{r}_{11}=0,651531$. Jika dibandingkan dengan nilai $\mathrm{r}$ product moment pada $\mathrm{df}=18$ dan pada taraf signifikan 5\% diperoleh nilai $r_{\text {tabel }}=0,444$. Maka dapat disimpulakn bahwa $r_{\text {hitung }}>r_{\text {tabel }}$ dan intrumen tersebut reliabel dijadikan alat pengumpul data.

\section{Uji Daya Beda Butir Soal}

Data hasil uji daya pembeda soal dapat dilihat pada Tabel 6 berikut.

\section{Tabel 6}

\section{Hasil Uji Daya Pembeda}

\begin{tabular}{|c|c|c|}
\hline Soal & Daya Pembeda & Interpretasi \\
\hline 1. & 0,65 & Baik \\
\hline 2. & 0,67 & Baik \\
\hline 3. & 0,65 & Baik \\
\hline 4. & 0,55 & Baik \\
\hline 5. & 0,25 & Cukup baik \\
\hline 6. & 0,45 & Baik \\
\hline
\end{tabular}

Berdasarkan hasil analisis butir soal untuk uji daya beda, diperoleh 5 soal yang memiliki daya pembeda yang baik, yaitu untuk soal nomor 1 memiliki nilai daya beda 0,65 dengan interpretasi baik. 
Soal nomor 2 memiliki nilai daya beda 0,67 dengan interpretasi baik. kemudian untuk soal nomor 3 dan nomor 4 memperoleh nilai daya beda yaitu 0,65 dan 0,55 dengan interpretasi baik. begitu juga untuk soal nomor 6 memperoleh nilai daya beda 0,45 dengan interpretasi baik. Sedangkan satu soal hanya memiliki interpretasi daya beda cukup baik, yaitu dengan dengan nilai daya beda hanya 0,25 .

\section{Uji Tingkat Kesukaran Butir Soal}

Berdasarkan analisis butir soal yang telah dilakukan, diperoleh hasil data seperti pada Tabel 7 berikut.

\section{Tabel 7}

Hasil Uji Tingkat Kesukaran

\begin{tabular}{|c|c|c|}
\hline Soal & Tingkat Kesukaran & Interpretasi \\
\hline 1. & 0,675 & Sedang \\
\hline 2. & 0,667 & Sedang \\
\hline 3. & 0,45 & Sedang \\
\hline 4. & 0,575 & Sedang \\
\hline 5. & 0,875 & Mudah \\
\hline 6. & 0,775 & Mudah \\
\hline
\end{tabular}

Berdasarkan tabel 7, dari 6 soal yang diberikan, terdapat 4 soal yang memiliki tingkat kesukaran sedang. Hal tersebut terlihat dari nilai interpretasi yang diperoleh soal yang berada diantar rentang $0,30<\mathrm{P} \leq 0,70$. Soal nomor 1 memperoleh nilai 0,675 dengan interpretasi sedang. Kemudian untuk soal nomor 2 memperoleh nilai 0,667 dengan interpretasi sedang. Untuk soal nomor 3 hanya memperoleh nilai 0,45 dengan interpretasi sedang. Terakhir untuk soal nomor 4 nilai yang diperoleh 0,575 dengan interpretasi juga sedang. Kemudian dua soal kemampuan komunikasi lainnya memperoleh tingkat kesukaran mudah, karena nilai interpretasi yang di peroleh berada pada rentang $0,70<\mathrm{P} \leq 1,00$. Terlihat dari soal nomor 5 yang memperoleh nilai 0,875 dengan interpretasi mudah dan soal nomor 6 dengan nilai 0,775 dengan interpretasi mudah.

\section{KESIMPULAN}

Berdasarkan hasil analisis butir soal yang diperoleh dari uji coba soal terhadap 6 buah soal kemampuan komunikasi matematika untuk materi relasi dan fungsi, diperoleh beberapa kesimpulan sebagai berikut, 1) dari segi validitas soal, diperoleh hasil analisis yang menyatakan bahwa keenam soal kemampuan komunikasi matematika pada materi relasi dan fungsi yang telah diuji cobakan dikategorikan valid. 2) dari segi reliabilitas soal, diperoleh hasil analisis nilai $r_{11}=0,651531$ lebih besar dari nilai $r$ tabel yaitu 0,444 sehingga dapat disimpulkan keenam soal kemampuan komunikasi matematika yang diujicobakan sudah reliabel untuk dijadikan sebagai alat ukur hasil belajar peserta didiki. 3) dari segi daya pembeda soal, diperoleh hasil analisis yaitu 5 soal dikatakan memiliki daya 
pembeda soal yang baik, yaitu soal nomor 1,2,3,4 dan 6, sedangkan untuk soal nomor 5 dikatakan memiliki daya pembeda soal cukup baik. 4) dari segi tingkat kesukaran soal, berdasarkan hasil analisis diperoleh kesimpulah bahwa 4 dari 6 soal memiliki tingkat kesukarang sedang, yaitu untuk soal nomor 1,2,3,dan 4. Sedangkan untuk soal nomor 5 dan 6 diklasifikasikan sebagai soal yang memiliki tingkat kesukaran soal yang mudah.

\section{DAFTAR PUSTAKA}

Ali Hamzah. (2014). Evaluasi Pembelajaran Matematika. Jakarta:PT. Rajagrafindo Persada.

Mardapi, J. (2008). Teknik penyusunan instrument tes dan nontes. Yogyakarta: Mitra Cendikia.

Firdaus. (2005). Meningkatkan kemampuan komunikasi Matematik Siswa Melalui Pembelajaran dalam Kelompok Kecil tipe Team Assisted Individualization (TAI) dengan Pengekatan Bebasis Masalah, (Tesis PPS UPI Bandung), h.4.

Fitzpatrick, J.L., Sander, J.R., \& Worthen, B.L. (2011). Program evaluation: alternative approaches and pratical guidelines. Boston: Pesron.

Halmaheri. (2004). Mengembangkan Kemampuan Komunikasi dan Pemecahan Masalah Matematis Siswa sltp Melalui Strategi Think-Talk-Write Dalam Kelompok Kecil, (Tesis PPS UPI Bandung, Tidak Diterbitkan, 2004).

Hartono. (2011). Metodologi Penelitian. Yogyakarta:Nusa Media. . (2010). Analisis Item Instrumen. Pekanbaru:Zanafa Publishing.

Hood, S., \& Hopson. R.K. (2008). Evaluation roots reconsidered: Asa Hilliard, a fallen hero in the "Nobody Knows My Name" project, and African Educational Exellence. Review of Education Research,h. 410-426

Karunia Eka Lestari dan Mokhammad Ridwan Yudhanegara. (2017). Penelitian Pendidikan Matematika. Bandung:PT. Refika Aditama.

Risnawati. (2008). Strategi Pembelajaran Matematika. Pekanbaru:Suska Press.

Saifuddin Azwar. (2013). Reliabilitas dan validitas. Yogyakarta: Pustaka Pelajar.

Stufflebeam D. L. \& Skinfield A.J (1984). Sistematic Evaluation. United States of America: Kluwer Nijhoff Publishing

Tika Dwi Rahayu, Bambang Hari Purnomo, Sudikin, (2014). Analisis Tingkat Kesukaran dan Daya Beda Pada Soal Ujian Tengah Semester Ganjil Bentuk Pilihan Ganda Mata Pelajaran Ekonomi Kelas X di SMA Negeri 5 Jember Tahun Ajaran 2012-2013, Jurnal Edukasi UNEJ, I(1): 39-43.

Zaenal Arifin. (2014). Evaluasi Pembelajaran. Bandung: PT Remaja Rosdakarya

Zamsir, Hasnawati. (2014). Model Diagnostik Kesulitan Belajar Siswa Berbasis Ujian Nasional, Jurnal Pendidikan Matematika Volume 5 Nomor 1 Tahun 2014, Hal 99-110. 